\title{
GEO-DISASTER LAHARIC FLOW ALONG PUTIH RIVER, CENTRAL JAVA, INDONESIA
}

\author{
Sugeng Sapto Surjono*and Andreas Yufianto \\ Geological Engineering Dept., Faculty of Engineering, Gadjah Mada University
}

\begin{abstract}
In 2011, laharic flow transporting volcanic materials had significantly occurred along Putih River, causing severe damage in Jumoyo area, Magelang, Central Java, Indonesia. The disaster happened frequently until April 2011. The approximately 150 million cubic meter of volcanic materials expelled from 2010 Merapi eruption has been assumed as main cause of recent laharic flow. Although pyroclastic deposit mostly flew to south and southeastern direction through Woro, Gendol, and Opak Rivers, laharic flow apparently flew to the west - westward directions through Putih and Pabelan Rivers. This study will explain the mechanism of such disaster along Putih River from sedimentological point of view.
\end{abstract}

Transport mechanism of laharic flow along river is strongly controlled by the slope and type of fluids. In the upper stream area, debris flow commonly occurs as gravity flow in the steep slope. To the downstream area, where more river and surface water infiltrates the volcanic material transportation, laharic flow mechanism transforms to hyperconcentrated flow. In the gently slope area, laharic flow decreases in concentration but increase in amount because of the accumulation influx from several river flows. Hyperconcentrated flow in Putih River is mostly generated by accumulation of river flow in the tributary area. In such area, loose volcanic materials are eroded easily by surface water. Rill and gully erosion bring volcanic material into main channel of Putih River, followed by intensive vertical erosion

${ }^{*}$ Corresponding author: S.S. SURJONO, Geological Engineering Dept., Faculty of Engineering, Gadjah Mada University. Jl. Grafika No. 2 Yogyakarta 55281, INDONESIA. E-mail: sugengssurjono@gmail.com along upper stream that will produce bigger accumulation of volcanic material within laharic flow in the downstream area. Several sabo dams along the Putih River were damaged during early period of laharic flow due to this transportation mechanism.

At the downstream of in Gempol Village, Jumoyo Area, the main channel of Putih River is shifting northwestward significantly due to Gendol Hill. On the other hand, river body in this settlement area is narrower compared to the upper stream area just before turning point. Both condition cause laharic flow to spill out from the channel and form an unconfined sheet debris flow with a $500 \mathrm{~m}$ width and around 2-4 $m$ thick sediments. Although energy of transport is reduced significantly, but this flow is still able to transport abundant volcanic material ranging from silt to boulder. Traditional market and hundreds of houses were buried and the main road from Yogyakarta to Magelang city has been disconnected for several times due to this disaster.

Keywords: Putih River, Laharic flow, Jumoyo

\section{Introduction}

Merapi Volcano $(2965 \mathrm{~m})$ is one of the most active volcanoes in the world. This volcano is located in Java Island in the border between Central Java and Yogyakarta Special Provinces with the peak coordinate of $7.542^{\circ} \mathrm{S} / 110.442^{\circ} \mathrm{E}$. Yogyakarta, the capital city of Yogyakarta Special Regions, is located around 30 kilometers to the south. Merapi is a stratovolcano with 50 slope in average up to 1300 meters high to 150 on the peak (Berthommier et al., 1990). On the west part of the volcano there is a fluviovolcanic plain area where in early 2011 experienced an immense laharic flow due to fluids that mixture 
with sediment load of volcanic material spill out and flooding from Putih River in Jumoyo area (Figure1).

Putih River has an upperstream in Merapi peak, flowing relatively straight to the southwest to Gendol Mountain. Fluviovolcanic plain in southwestern Merapi is interpreted as the product of Putih and Blongkeng Rivers activities (Kurniawan, 2008). This river has only small debit flow in the dry season whereas in the wet season the water flow accumulates in the Putih River valley, forming a high debit flow. Putih River experiences a shifting river channel to the northwest direction in the Jumoyo area due to the obstruction of the main river flow by Gendol Hill. Therefore, the river cannot support the laharic flow in the greatest amount. Thus, the lahar flows over the main channel.

The purpose of this research is to identify the 2011 laharic flood impact along the Putih River and to understand the laharic flow mechanism along Putih River and in Gempol, Jumoyo area and formulate solution to reduce the negative impact of the laharic flow. This research is conducted using interpretation of topographic and geological maps, literature studies and fully supported by data from direct investigation in the field.

\section{Characteristics of Merapi Volcano}

Merapi Volcano has a specific type of eruption, namely Merapi type. The eruption is catagorized as explosive, produces lava flow, causes flank collapse, produces dome in the peak and sometimes produces pyroclastic flow and hot avalanche (nuee ardente). A big Merapi eruption occurs for at least once in every 1000 years. Before the 2010 eruption, the last eruption that is considered as big eruption happened in 1872 and classified into vulcanian-subplinian explosion with Volcanic Explosivity Index (VEI) = 4 (Newhall and Self, 1982). The first Merapi explosion in 2010 occurred on October 26 followed by several explosions and finally decline in activity on December 3, 2010. There had been a big explosion on November 5, 2010 that created an explosive column. The Volcanology
Center of Meteorology and Geophysics Board (VCMGBG) estimated 150 million meter cubic of volcanic material that had been expelled in the peak area and then spreaded out to the southern and western part of Merapi Volcano.

From the volcanological point of view, Merapi is classified as a stratovolcano which is composed by fragmental materials that are easily transported in big volume (Fisher and Smith, 1991). Rock composing the Merapi Volcano is mainly basaltic andesite. In Merapi flanks, volcaniclastic material flows downhill along the slope through the river valleys. This fluid flow which in the Javanese language is called lahar,is a mixture of volcaniclastic debris and water flowing down the stratovolcano slopes in relatively high speed (van Bemmelen, 1949). Lahar has a destructive character and is strongly erosiv that it can destroy anything in its way if the flow is of a massive volume. There are three main factors supporting the formation of Merapi's lahar: (1) pyroclastic sediments in the amount of million cubic deposited by pyroclastic flow within 2-4 years time, (2) high rainfall intensity (averagely of 40 millimeters within 2 hours) during the rainy season from November until April, and dense distributary pattern in Merapi flanks (Lavigne and Thouret, 2002). The formation of laharic flow disaster is often associated with heavy rainfall following a big Merapi eruption. Usually, laharic flow happens a few minutes after a heavy rain. The most humid season occurs from December until February when rain volume can reach up to $800 \mathrm{~mm} /$ month and $600 \mathrm{~mm} / \mathrm{month}$ in average. Data for Putih River from 1984-1990 shows that $86 \%$ of the laharic flow occured at the rainy season (Lavigne et al., 2000).

Generally, laharic flow consists of debris flows and hyperconcentrated flows (Fisher and Smith, 1991). Hyperconcentrated flow that contains $40-60 \%$ of concentrated volcanic materials is a non-cohesive mass flow which is loose sediments, rarely found in layers, reverse grading and low density material at the base of deposits (Scott, 1988). Debris flow has $60-80 \%$ of concentrated volcanic material with relatively equant fragment, especially for big size material. Sedimentary structure in the debris 

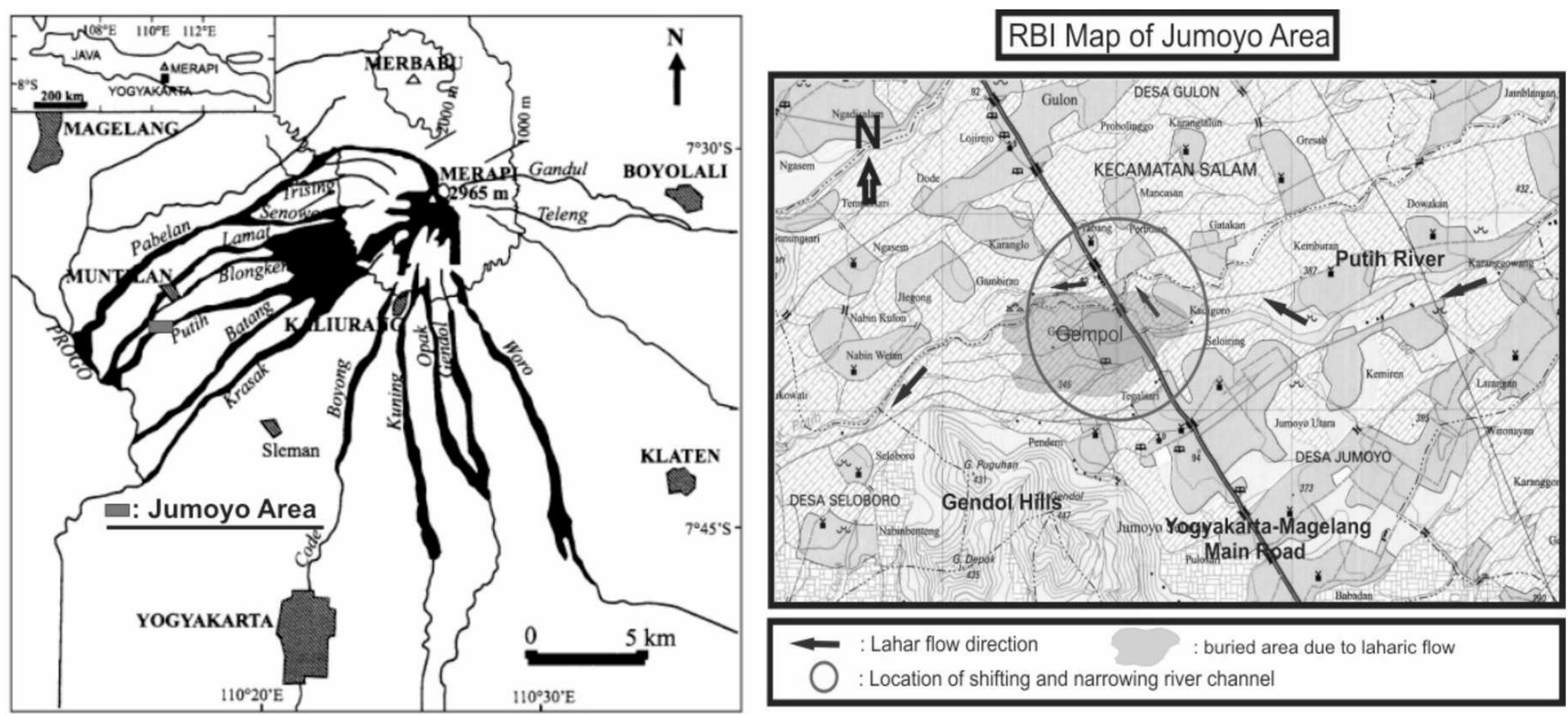

Figure 1: Laharic flow 2011 occurred at Gempol Village, Jumoyo area. Located around $15 \mathrm{Km}$ southwest of Merapi's summit (left figure). It also point out the distribution of volcaniklastic of Merapi [6]. Distribution of buried area due to laharic flow including Yogyakarta-Magelang main road (right figure)

flow is pre depositional or erosion of scour with no syn-depositional structure or massive sedimentary structure. Hyperconcentrated and debris flows have an important role to make volaniclastic material able to be transported to far location up to Jumoyo area (approximately 15 kilometers to the southwest direction from the peak).

\section{Damages due to laharic flows}

Laharic flow has caused damages in several places along Putih River flow. The laharic flow eroded the river base and riverside causes deepening and widening of river channel. This condition endangers houses and construction located in the riverbank. Several artificial riverbank and dams constructed by inhabitants were damaged by this erosion. According to Lavigne et al.,(2000), local landslide caused by riverside base erosion is an important source of additional debris (Lavigne et al., 2000).

After the eruption, laharic flow and flashflood occur due to transport sediments by sheet, rill and gully erosion in the relatively upper stream area (Lavigne et al., 2000a). In the upper stream area, the laharic and surface flow generates rill erosion damaging some of inhabitant's land. Rill erosion forms channels where surface water that mixes with volcaniclastic material flow together in a debris flow as well as in hyperconcentrated flow which are then concentrated to the Putih River. Besides that, several river flows are also linked to Putih River, such as Blongkeng, Batang and Lamat Rivers that were blocked to make the river flow accumulated to the Putih River (Figure 2).

Volcanic material of the 2010 Merapi eruption which was deposited in the western flank caused damage to vegetation and inhabitant's land. They were buried by landslide material and thick volcanic ashes. The lost of vegetation in the upper stream area has triggered the increasing level of erosion (Fisher and Smith, 1991). Therefore, rill erosion would then form small channels that was connected to each other. This channel became the media to transport the mixture of fluids and volcanic material as the origin of laharic flow.

There are several sabo dams along the Putih River made to protect the laharic flow disaster. Some of them were already fullfilled by volcanic material and others were damaged due to laharic flow activity. The broken sabo dam is 


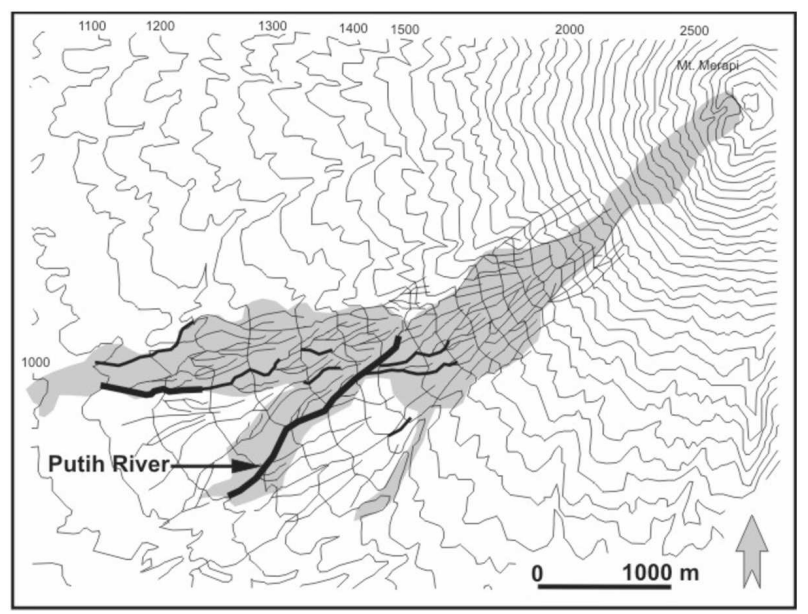

Figure 2: Distribution of erosional pattern in the southwestern flank of Merapi. Data taken in August 1991 by Simokawa et al. (vide Lavigne et al., 2000a)

interpreted as one of the factors causing the big flood in Jumoyo. Volcanic material sediment in several sabo dam totally covered dam valley and reduced dam capacity in retaining laharic flow. The following laharic flow will spill out through middle part of sabo dam as well as base of river side. 2011 laharic flow also destroy several traditional and modern construction bridges connecting both river side.

Jumoyo Area (Gempol Village), Magelang, Central Java is the worst area destroyed by the 2011 laharic flow. This area is located exactly in front of the river channel where it changes the flow direction and narrowing the river valley. Laharic flow spilled out due to incapability of river body to retain mixture of fluids and volcanic material flows. The high flowing speed makes the lahar tends to move forward straightly and difficult to turn to other direction. Although energy of laharic flow is reduced significantly, the flow is still capable to transport abundant volcanic material ranging from silt to $5 \mathrm{~m}$ diameter of boulder. In the river turning area, laharic flows were spreaded out to all direction, causing almost all inhabitant's houses in front of the flow swept out by the laharic flow. Dimension of damage area due to laharic flows is around $500 \mathrm{~m}$ in width with around 2-4 m of sediment's thick (Figure 3 a). Traditional market and hundreds of houses were buried and the main road from Yogyakarta to Magelang city was disconnected for several times due to this disaster (Figure $3 \mathrm{~b}$ ). Spill out of the flood material also caused erosion of the river base for approximately two meters. Surjono dan Amijaya have resume that the impact of laharic flow is around 90 houses damaged and 5000 people become refugee (Surjono and Amijaya, 2010).

\section{Mechanism of the laharic flow along Putih River}

Commonly, laharic flows along Putih River are triggered by rainfall, hence rain-laharic flow is also termed to Merapi type lahar. The frequencies of this type of laharic flow depend on intensity and duration of rainfall (Lavigne and Thouret, 2002). Heavy rain in the upper stream area are considered as the main potential to trigger the debris flow which then subsequently followed by channel formation due to rill erosion. Channels in the upper stream are interconnected to form larger and deeper channel stream where laharic flow increase in capacity and competency in a tributary system (Pierson et al., 1990). In the tributary area, laharic flow density decrease significantly due to dilution, where surfaces water influx to the high concentrated fluids. Dilution process transforms debris flow to more mobile hyperconcentrated flow which can reach further area in the downstream. During transportation to the lower stream, fluids flow can return back to be debris flows due to bulking process by influx volcanic material along stream channel. Apart from rainfall, several factors may also trigger laharic flows including (1) degree of slope and channel gradient; (2) volume and thickness of source sediments; (3) physical properties of phyroclastic deposits such as permeability, pore pressure and grain size; (4) covered vegetation in the upper stream area (Lavigne and Thouret, 2002).

Putih River receives a lot of surface fluids from another small rivers as well as intermittent channel resulting higher debit flow to the lower stream area. The most dangerous area in term of laharic flow threatens in Merapi area is located in the southwestern flank area 

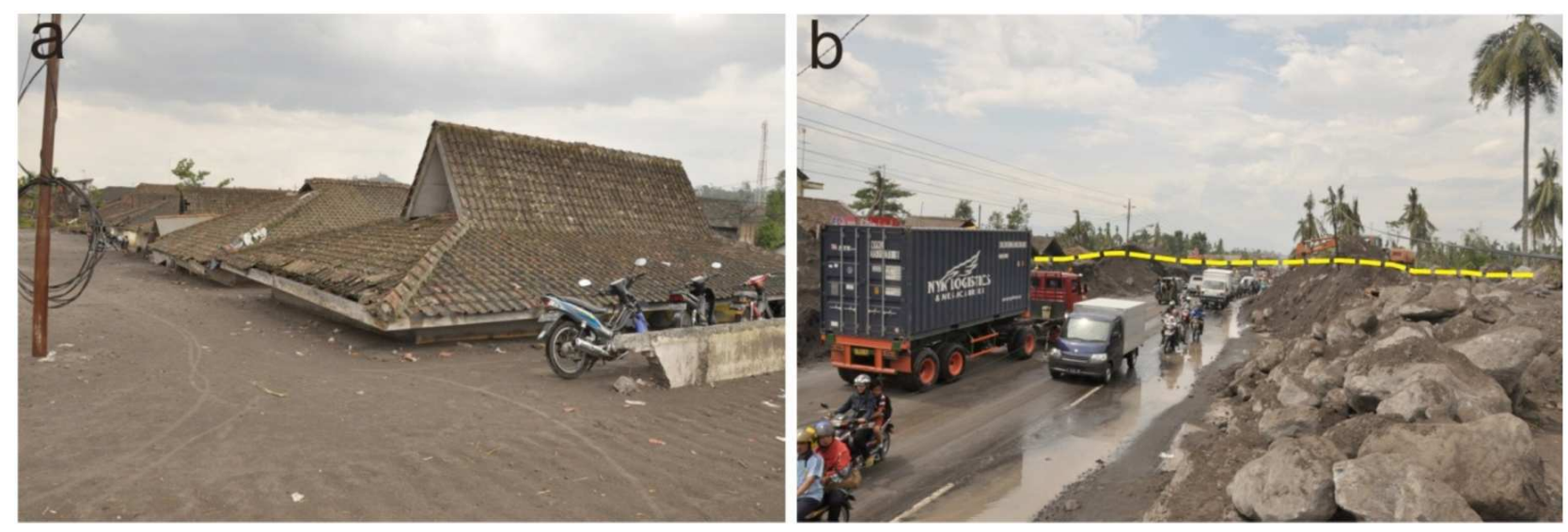

Figure 3: a) Residences and traditional market were buried by 2-4 $\mathrm{m}$ of laharic flow deposits. b) Re-opening Yogyakarta-Magelang main road after blocked by laharic flow deposits

where Putih, Bebeng and Blongkeng Rivers flows from the summit area. Blongkeng channel artifically was blocked after 1969 eruption while its pyroclastic and laharic flows were directed and connected to Putih River (Lavigne et al., 2000). After 2010 eruption, laharic flow in the Putih River was experienced a huge amount of debris and hyperconcentrated flows with velocity around $60 \mathrm{~km} /$ hour in the lower flank area. Based on the characteristics of deposits along river flow, it can be interpreted that fluids flow type along the river is transition of debris flow to hyperconcentrated flow. Laharic flow along Putih River is typically being vertically erosive because this area is highly located from base level of erosion. The high intensity of vertical erosion cause increasing transported volcanic material as well as their destruction power along stream flow. Several sabo dams buit to prevent annual laharic flow along Putih River were broken by 2011 laharic flow. Vertical erosion and eddy current occurred in the front foot of sabo dam are considered as the main control for destruction mechanism of sabo dam (Figure 4a). Eddy current is a highly mass turbulent current (Leeder, 1982) occur in front of a current barrier (obstacle) or in the bottom of ripple formed by laminar current. Along the Putih River, this current is interpreted to be more intensively eroded in the front (downstream) foot of the dam resulted a big hole below of the dam base (Figure $4 \mathrm{~b}$ ), and therefore become new river channel. Sabo dam will be to- tally broken if this current type flows for several times over the sabo dams during rainy season.

Debris flow deposits are characterized by thickly bedded layers with poorly to very poorly sorted texture, matrix supported, random clast orientation, composed by mixture clay to boulder grain-sized sediments and no sedimentary structures (Boggs, 1987). Hyperconcentrated flow results in sediments with poorly sorted texture, grain-supported with less fragments and smaller fragment size (pebble-cobble). Both fluid flow can transform to the other type due to dilution (addition of water/fluids) or bulking (addition of sediment load) in the laharic flow system (Fisher, and Smith, 1991). Increasing water or fluid results in fluid flow more mobile, while increasing sediment load results in higher destruction fluid power. On the other hand, the increasing sediments load into fluid flow may also reduce the current or totally deccelerate it since there are too much sediments load to carry (en masse freezing). If debris flow is having dilution, this fluid current will transform to the hyperconcentrated flow, and if the dilution process is continued, fluid will be a normal/dilute stream flow. The process of water infiltration is caused by water accumulation from channels and river branch into main channel of Putih River as well as from surface water resulted by heavy rain in the wet season. Water supply from Putih River also donated by springs occurs along riverside. Further from the source of sediments, the 


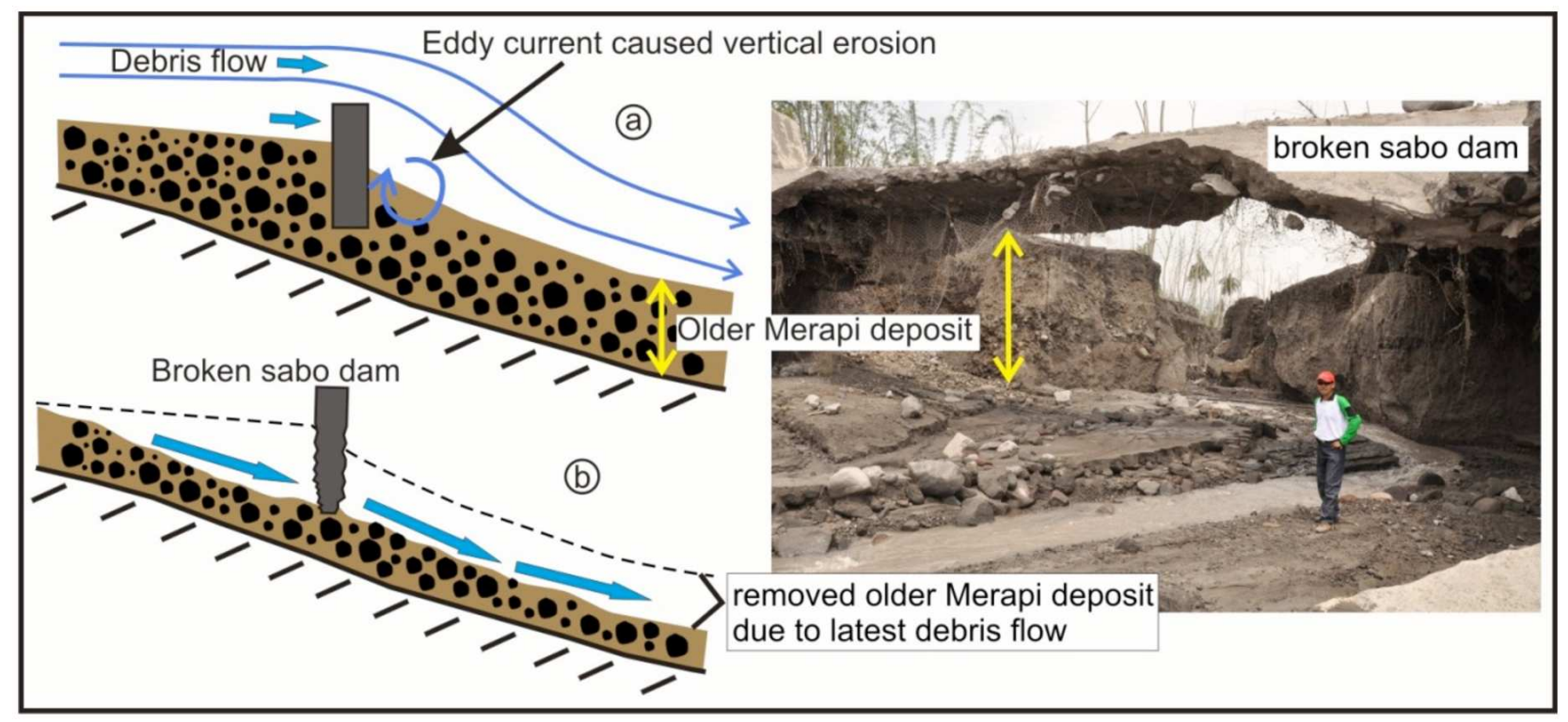

Figure 4: Mechanism of destroying sabo dam along Putih River due to laharic flow. a) Eddy current eroded old Merapi deposit more intensive in foot of dam. b) Vertical erosion caused increasing concentration of solid material and energy of laharic flow

stream competency will be decreased but the stream capacity will be increased due to the increasing volume of water so that the amounts of sediments load is also raised. Debris flows gradually transform to hyperconcentrated flow through this mechanism.

Transformation of debris flow - hyperconcentrated flow - normal/dilute stream flow is controlled by several factors, i.e.:

1. Laharic flow occur more than one event, therefore volcanic material deposited earlier can be reworked or re-transported by subsequent laharic flow.

2. Different of intensity and uneven distribution of rainfall.

3. Increasing debit and volume of fluids flow due to broken sabo dam in the upper stream area.

4. Volcanic material mining along river body which reduces deposits significantly and change morphology built by volcanic deposits.

In the Gempol Village-Jumoyo area, Putih River shifted/turned around $75^{\circ}$ to the right from the main direction flow (southwest) to the relatively northwestward. This shifting is controlled by topographic condition where Gendol
Hill is stand in front of Putih River, blocked the natural stream flow and guides it to the lower topography. The stream flows back to the main direction somewhere around $500 \mathrm{~m}$ northwest of first turning point and cross the main road connecting Yogyakarta - Magelang. In the shifting river in Jumoyo area, dimension of Putih River reduce dramatically form 15 $\mathrm{m}$ wide and $6 \mathrm{~m}$ deep before turning point to the $5 \mathrm{~m}$ wide ad $4 \mathrm{~m}$ high below the bridge of Yogyakarta - Magelang main road (see Figure 1). This contrasting capacity is also considered to be main factor of the laharic flow spill out from the main channel. There are two types of distribution of laharic flow which is influenced by slope morphology along volcano that are the confined and unconfined flow (Rodolfo and Tevfik, 1991). At the first turning point, laharic flow having spilled out, flowing out of channel and forming unconfined sheet debris flow. The fluid flow tranformation will influence in reducing transport energy, destroying power and swept acreage. Some houses and other building were not totally damaged and still able to retain laharic flow although half of them were buried by laharic deposits. However, field investigation shows that boulder size deposits in this area reach $5 \mathrm{~m}$ in diameter. The sheet flow 
caused area of swept to be wider than that flow within channel. During disaster events in January - April 2011, area which was swept reach $500 \mathrm{~m}$ of width with sediment thickness around 2-4 $\mathrm{m}$ and total acreage was 9 hectare. Those sediments were resulted by several events of laharic flow during that session.

\section{Hazard Mitigation}

The laharic flow disaster happened in the rainy season where the rain intensity is high. Considering to the amount of volcanic material erupted by Merapi Volcano in the end of 2010 and the amount of material which were already deposited and transported along river flow, the Putih River still keep big a potential to have the laharic flows disaster in the future. There are several factors causing the increasing risk of laharic flow in the area, as follows:

1. The huge amount of loose volcanic material deposited in the upper stream area and along Putih River's channel which ready to be transported anytime and transformed to be laharic flow.

2. Decreasing river capacity in several location / point area because sabo dams were already fulfilled by deposits. When these dams broke down, they supported a huge of sediment as laharic flow sediments transported to the lower stream area.

3. There are many traditional mining activities along river body to collect sand and gravel of volcanic deposits without any preventive or enough anticipation for sudden laharic flow.

4. The effort to maintain Putih River channel in Jumoyo area to be the same with condition before disaster event can cause a spill out of laharic flow in the future and also sheet debris flow is still a threat to this area.

Continuous monitoring is needed in order to prevent and anticipate following disaster including laharic flow occurred after volcanic eruption (Scarpa and Tilling, 1996). The following activities are efforts for reducing disaster impact which may occur in the next rainy season, including:
1. Reforestation in the upper stream area to minimize rill and gulley erosion due to sheet flow during or after rainfall.

2. Build artificial river bank in the selective riverside to prevent lateral erosion and landslide which can increase volcanic material content in the fluid flow.

3. Distribute Putih River flow to other river, such as Blongkeng, Batang and Lamat Rivers for reducing fluid volume flowing in Putih River.

4. Create laharic disaster vulnerable map along River Putih and surrounding.

5. Give information to traditional miners and inhabitants living alongside River Putih for always in caution to laharic flow disaster that can happen anytime.

6. Set up early warning system equipment to monitor laharic flow in several locations along Putih River.

7. Built or strengthen sabo dams, mainly which is filled by laharic sediment of Merapi to prevent possibility of broken dam if there are big river flow.

8. Create new straight channel in Gempol village, Jumoyo area to avoid turning and narrowing channel in that area. The new channel should big enough to flow laharic fluid of River Putih in that area.

\section{Conclusions}

Laharic flow along Putih River is the debris flow and hyperconcentrated flow types transporting mixture of volcaniclastic material from old Merapi deposit and the product of OctoberNovember 2010 Merapi eruption. This lahar is triggered by the high intensity of rainfall, especially during January to April 2011. Rain in the upper stream causes intensively rill erosion and gulley erosion to form channels with dense distributary pattern and transporting water and volcanic material mixture to the main channel of Putih River. The increase of river flow in Putih River is also supported by the blockade of other big rivers and let the surface water flow into the Putih River.

Jumoyo area is the worst area destroyed because the laharic flow spill out from the main 
channel due to turning and narrowing of Putih River valley. Laharic flow changes to unconfined sheet debris flow and cover Jumoyo area and surroundings with the deposit thickness up to 4 meters in the area of 9 hectares and disconnect the main road of Yogyakarta - Magelang. This laharic flow is still possible to happen on the peak of the next rainy season, hence we need to lessen the negative impact from this lahar by strengthening the sabo dam construction, constructing artificial bank in the area which have landslide potent, reforestatinge upper stream to lessen erosions and constructing new channel in Gempol Village to keep lahar flowing within the main channel.

\section{References}

Berthommier, P., Camus, G., Condomines, M., Vincent, P.M. (1990). Le Merapi (Centre Java): elements de chronologie d'un strato-volcan andesitique. C.R. Acad. Sci. Paris.

Boggs, S. Jr. (1987) Principles of Sedimentology and Stratigraphy, Merryl Publishing Co., Ohio.

Fisher, R. V. and Smith, G. A. (1991) Sedimentation in Volcanic Setting, Society for Sedimentary Geology, Oklahoma.

Kurniawan, A. (2008) The Truth about Paroxysmal Merapi Volcano's Eruption from Geomorphology of Southwestern Merapi's Fluviovolcanic Plain, Proceeding International Geomorphologist Seminar Yogyakarta, Indonesia.

Lavigne, F. and Thouret, J.C. (2002) Sediment transportation and deposition by rain-triggered lahars at Merapi Volcano, Central Java, Indonesia, Geomorphology, Vol 49, p 45-69.

Lavigne, F., Thouret, J.C., Voight, B., Young, K., La Husen, R., Marso, J., Suwa, H., Sumarsono, A.,
Sayudi, D.S. and Dejean, M. (2000) Instrumental lahar monitoring at Merapi Volcano, Central Java, Indonesia, Journal of Volcanology and Geothermal Research, Vol 100, p. 457-478.

Lavigne, F., Thouret, J.C., Voight, B., Suwa, H. and Sumaryono (2000a) Lahars at Merapi volcano, Central Java: an Overview, Journal of Volcanology and Geothermal Research. Vol. 100, p. 423456.

Leeder, M.R. (1982) Sedimentology-Process and product, George Allen \& Unwin, London.

Newhall, C.G. and Self, S. (1982) The Volcanic Explosivity Index (VEI): An Estimate of Explosive Magnitude for Historical Volcanism. Journal of Geophysical Research, Vol. 87 (C2), p. 1231-1238.

Pierson, T.C., Janda, R.J., Thouret, J.C., Borero, C.A. (1990) Perturbation and melting of snow and ice by the 13 November 1985 eruption of Nevado del Ruiz, Columbia and consequent mobilization, flow and deposition of lahars. Journal of Volcanology and Geothermal Research, Vol. 41, p. 17-66.

Rodolfo, K. S. and Tevfik, A. (1991) Rain-Lahar Generation and Sediment Delivery System at Mayon Volcano Philippines, SEPM, Chicago.

Scarpa, R. and Tilling, R.I. (1996) Monitoring and Mitigation of Volcano Hazards, Springer, New York.

Scott, K. M. (1988) Origin Behaviour and Sedimentology of Lahars and Lahars Runout Flows in Toutle-Cowlitz River System: USGS Professional Papers.

Surjono S.S. and Amijaya, D.H. (2010) Sedimentological Geohazard by post 2010 eruption laharic flow of Merapi Volcano, Indonesia, Abstract of 28th IAS Meeting of Sedimentology, Zaragoza 5th-8th July 2011.

Van Bemmelen, R.W. (1949) The Geology of Indonesia, Vol. 1A, Government Printing Office, The Hague, Amsterdam. 